\title{
USE OF POULTRY LITTER, SWINE MORTALITY COMPOST, AND FGD GYPSUM ON RECLAIMED LIGNITE MINE SOIL IN MISSISSIPPI ${ }^{1}$
}

\author{
J.J. Read ${ }^{2 *}$, A. Adeli, D.J. Lang, and N.R. McGrew
}

\begin{abstract}
Knowledge of soil and plant responses to animal or industrial byproducts is needed for effective use of these amendments on reclaimed mine soils. A 5-yr study (2011-2015) at a surface lignite mine in northeast Mississippi determined soil chemical, common bermudagrass, and loblolly pine responses to animal waste and flue gas desulfurization (FGD) gypsum. The study was a randomized complete block design with three replicates consisting of the annual application of 22.4 $\mathrm{Mg} \mathrm{ha}^{-1}$ poultry litter, $22.4 \mathrm{Mg} \mathrm{ha}^{-1}$ swine mortality compost, and $896 \mathrm{~kg} \mathrm{ha}^{-1} \mathrm{NPK}$ fertilizer (13-13-13; the standard practice), with and without co-application of 11.2 $\mathrm{Mg} \mathrm{ha}^{-1}$ FGD gypsum. Soil amendment treatments were incorporated to $15 \mathrm{~cm}$ depth in May 2011 and applied without incorporation in 2012-2015. Soil samples were collected each year at 0 to $15 \mathrm{~cm}$ and 15 to $30 \mathrm{~cm}$ depths. Analysis of surface 0 to $15 \mathrm{~cm}$ soil depth in December 2015 indicated greater $\mathrm{pH}$, organic matter, and extractable P with poultry litter than NPK fertilizer; whereas, total CEC differed slightly $(\mathrm{P}<0.10)$ between these treatments $\left(22.9\right.$ vs. $\left.20.2 \mathrm{cmol}(+) \mathrm{kg}^{-1}\right)$. The coapplication of FGD gypsum with poultry litter, swine compost, and NPK fertilizer decreased organic matter of surface soil in December 2015 by approximately 33, 6, and $12 \%$, respectively. In subsurface 15 to $30 \mathrm{~cm}$ soil depth, $\mathrm{pH}$, organic matter, and available $\mathrm{P}$ and $\mathrm{K}$ levels did not differ among amendment treatments. Applying poultry litter in 2011 generally improved bermudagrass vigor and canopy height as the plants became established. Annual DM yield was affected by soil amendment, year, and their interaction and its ranking among fertility treatments in 2012-2014 was poultry litter $>$ NPK fertilizer $=$ swine compost. The height/diameter ratio of loblolly pine was least with poultry litter, suggesting these trees have improved stability. Repeatedly applying poultry litter improved soil fertility and plant growth parameters in a respread area.
\end{abstract}

Additional Key Words: bermudagrass, composted swine mortalities, fertilizer, land reclamation, manure, nitrogen, oxidized overburden, soil organic matter.

${ }^{1}$ Poster paper presented at the 2018 National Meeting of the American Society of Mining and Reclamation, St. Louis, MO: The Gateway to Land Reclamation, June 3 - 7, 2018. Published by ASMR; 1305 Weathervane Dr., Champaign, IL 61821.

2 John J. Read, Research Agronomist, USDA-ARS, Crop Science Research Laboratory, 810 Hwy 12 E, Mississippi State University, Mississippi State, MS 39762; Ardeshir Adeli, Research Soil Scientist, USDA-ARS, Crop Science Research Laboratory, 810 Hwy 12 E, Mississippi State University, Mississippi State, MS 39762; David J. Lang, Professor, Plant and Soil Sciences Department, Mississippi State University, Mississippi State, MS 39762; N. Rebecca McGrew, Environmental Manager, North American Coal Corporation, 5340 Legacy Dr \# 300, Plano, TX 75024

DOI: $\underline{\text { http://dx.doi.org/10.21000/JASMR19020031 }}$ 


\section{Introduction}

Coal mining at the Mississippi Lignite Mining Company, Red Hills Mine is permitted on approximately 2,350 ha $(5,800$ acres), most of which is being restored to loblolly pine (Pinus taeda) forest. Typically, pine seedlings are planted to a respread area following a one- to two-year period of forage grass production, as rapid establishment and growth of these grasses helps to stabilize the respread soil. In a study to characterize productivity of respread soils, Lang et al. (2008) reported growth of annual ryegrass (Lolium multiflorum) in oxidized overburden strata collected to a depth of $9.6 \mathrm{~m}$ was similar to or exceeded growth in topsoil collected to a depth of $0.3 \mathrm{~m}$. They concluded that mixtures of topsoil and oxidized overburden strata provide a superior reclamation option compared with regulatory requirements of salvaging and respreading topsoil.

A range of reclamation techniques is available for mine soils, including the addition of fertilizer and organic matter to improve soil quality and productivity (Hearing et al., 2000). Thus, there is potential to use animal waste products generated by confined animal feeding operations, such as poultry litter (a mixture of manure, wasted feed, and bedding materials) and composted swine mortalities (a mixture of poultry litter, sawdust, and swine carcasses). Amending soils with manure and organic residues has been shown to improve nutrient availability, water holding capacity, soil aggregate stability, and crop productivity (Haynes and Naidu, 1998; Bendefeldt et al., 2001; Read et al., 2006; Evanylo et al., 2008). Such restorative functions may help to establish vegetation on surface-mined soils by overcoming the biological, chemical, and physical characteristics that are unfavorable to plant growth and soil development. Characteristics typical of respread soils at the Red Hills Mine include moderate bulk density and water holding capacity and low organic $\mathrm{C}$ concentration.

In 2007, an estimated 25 million metric tons of poultry litter, $48 \%$ of total poultry litter in the U.S., was produced in Arkansas, Alabama, Georgia, and Mississippi (USDA, 2009). Like poultry litter, swine mortality compost is a promising organic soil amendment due to its relative availability in the region. The benefits of poultry litter for agricultural production systems are well known, but few studies have determined crop responses on reclaimed mine soil. Edwards and Daniel (1992) reported poultry litter increased soil organic matter and the supply of essential plant nutrients.

A byproduct of the electric utility industry, produced from a process known as flue gas 
desulfurization, is FGD gypsum. It is created by forced oxidation scrubbers attached to coal-fired power plants to limit sulfur emissions. This process produces a consistent finely divided powder that, except for various trace materials, is otherwise chemically equivalent to gypsum $\left(\mathrm{CaSO}_{4} \mathrm{x}\right.$ $2 \mathrm{H}_{2} \mathrm{O}$ ). Although gypsum is known to be a good soil amendment, little is known about chemical processes occurring in soils when gypsum and manure are applied together. However, mismanagement of poultry litter $\mathrm{N}$ can result in $\mathrm{N}$ losses due to volatilization of ammonia $\left(\mathrm{NH}_{3}\right)$ or leaching of $\mathrm{NO}_{3}-\mathrm{N}$ when $\mathrm{N}$ mineralization is more rapid than plant uptake (Coyne et al., 1998; Sharpe et al., 2004). Including FGD gypsum as a "binding agent" for $\mathrm{NH}_{4}-\mathrm{N}$ and as a "soil conditioner" may reduce $\mathrm{N}$ losses to the environment. The combination of FGD gypsum and manure may improve soil $\mathrm{C}$ sequestration by slowing the breakdown of added $\mathrm{C}$. This is because gypsum enhances soil aggregate formation and soil micro-aggregates can protect soil $\mathrm{C}$ from decomposition.

At Red Hills Mine, a mixture of topsoil, subsoil, and oxidized overburden that provides for biota reestablishment is referred to as oxidized material and is used as substitute soil for upland restoration (Lang et al., 2005; Lang et al., 2006). Studies on reclamation of coal mine soils indicate organic C plays a key role in the improvement of soil physical and biological properties (Shrestha et al., 2007; Shrestha and Lal, 2008). For example, Boerner et al. (1998) reported increases in soil $\mathrm{N}, \mathrm{P}$, and organic matter in a reclamation chronosequence. Soil organic matter is reduced when soil $\mathrm{C}$ is exposed to atmospheric conditions ( $\mathrm{C}$ oxidation) and through dilution of soil $\mathrm{C}$ due to horizon mixing during surface coal mining as well as respreading activities. Increasing soil organic $\mathrm{C}$ with the addition of poultry litter or swine mortality compost will potentially enhance restoration; however, the added organic matter is readily bioavailable and decomposes by microbial activity in the soil. Soil organic $\mathrm{C}$ acts as a binding agent and can strongly affect a number of soil quality parameters, including nutrient cycling, plant available water, and microbial activity (Haynes and Naidu, 1998; Hearing et al., 2000). Chatterjee et al. (2009) suggested newly reclaimed coal mine soil is often low or deficient in $\mathrm{N}$ because of low organic matter levels and a lack of effective $\mathrm{N}$ cycling.

The objective of this 5-year study (2011 to 2015) was to determine growth responses of common bermudagrass and loblolly pine to soil amendment treatments with and without FGD gypsum and associated changes in soil organic matter and nutrient concentration. Results of this study will aid in informing reclamation ecologists on safe and effective use of animal and industrial 
byproducts as soil amendments after surface mining of coal in Mississippi.

\section{Methods}

The study area was a newly reclaimed mine soil that was typical for the lignite mining operations at the Red Hills Mine located near Ackerman, MS (33 $\left.22^{\prime} 55.5^{\prime \prime} \mathrm{N} ; 89^{\circ} 15^{\prime} 27^{\prime \prime} \mathrm{W}\right)$. This reclaimed soil was characterized as a mixture of primarily oxidized overburden materials. Respread was placed in fall 2010 and winter-spring 2011. Reclaimed soils at Red Hills Mine have been tentatively classified as fine-loamy, siliceous, active, nonacid, thermic Alfic Udarents and the proposed Redhills Series is presently under review as a product in the National Cooperative Soil Survey (E.F. Janak, Jr., CPSS, personal communication, 2018). Documentation for the proposed Redhills Series indicates that parent material of the overburden materials was derived from Tertiary age sediments, mainly of the Wilcox Formation (https://mrdata.usgs.gov/geology/state/sgmc-unit.php?unit=MSEOw\%3B0) and reclamation following disturbance by mining activities at the Red Hills Mine has been in progress since 1999.

Three types of waste materials were used as soil amendments: poultry litter, composted swine mortalities, and FGD gypsum. Poultry litter was obtained from a commercial broiler chicken farm near Macon, MS. Swine compost was obtained from a commercial swine farm near Crawford, MS. Flue gas desulfurization gypsum was obtained from Southern Company, Atlanta, GA. Table 1 summarizes some nutrient characteristics of these materials on a dry weight basis. Total $\mathrm{N}$ and $\mathrm{C}$ was determined by combusting $25 \mathrm{mg}$ samples using a ThermoQuest $\mathrm{C} / \mathrm{N}$ analyzer (CE Elantec, Lakewood, $\mathrm{NJ})$. Inorganic $\mathrm{N}\left(\mathrm{NO}_{3}-\mathrm{N}\right.$ and $\left.\mathrm{NH}_{4}-\mathrm{N}\right)$ was determined by extracting 2-g samples with 2 M KCL (1:10 ratio) followed by colorimetric analysis using a Lachat QuickChem FIA+8000 flow injection analyzer (Hach Co., Loveland, $\mathrm{CO}$ ). Total P, K, $\mathrm{Ca}, \mathrm{Mg}, \mathrm{Na}$, and Fe were determined by dry ashing and acid extraction of samples followed by analysis using inductively coupled plasma spectrometry techniques with an Iris Advantage ICP (Thermo Jarrel Ash, Houghton, MI). Total N concentration of poultry litter and swine compost was 26.5 and $13.7 \mathrm{~g} \mathrm{~kg}^{-1}$, respectively, and was undetectable in the FGD gypsum material. Total $\mathrm{Ca}$ and $\mathrm{Na}$ concentrations of FGD gypsum were below the range reported in the literature of 185 to $243 \mathrm{~g} \mathrm{~kg}^{-1} \mathrm{Ca}$ and 0.23 to $58 \mathrm{~g} \mathrm{~kg}^{-1} \mathrm{Na}$ (OSU, 2006). The concentration of other nutrients and the trace elements was generally low within the range of reported values for FGD gypsum.

A randomized complete block experimental design with three replicates was used and each 
plot received the treatment that was assigned at the onset of the study. Individual plots were $3.65 \mathrm{~m}$ wide x $12.19 \mathrm{~m}$ long (12 x $40 \mathrm{ft}$ ) and replicate blocks were separated by a $3.65 \mathrm{~m}$ alley. The six treatments consisted of annual application of $22.4 \mathrm{Mg} \mathrm{ha}^{-1}$ poultry litter; $22.4 \mathrm{Mg} \mathrm{ha}^{-1}$ swine compost; $896 \mathrm{~kg} \mathrm{ha}^{-1}$ NPK fertilizer (13-13-13; standard reclamation treatment used by Red Hills Mine in the first year only); poultry litter $+11.2 \mathrm{Mg} \mathrm{ha}^{-1}$ FGD gypsum; swine compost $+11.2 \mathrm{Mg}$ $\mathrm{ha}^{-1}$ FGD gypsum; and NPK fertilizer + 11.2 $\mathrm{Mg} \mathrm{ha}^{-1}$ FGD gypsum. The poultry litter, swine compost, and FGD gypsum were chopped to a uniform size to provide a consistent product that could be weighed easily and distributed uniformly by manual techniques. These materials were applied on an as-is moisture basis. Subsamples of poultry litter and swine compost were dried at $100{ }^{\circ} \mathrm{C}$ for 48 hours to determine percentage dry matter (DM) (Table 1). On 11 May 2011, the soil amendment treatments were incorporated to a $15 \mathrm{~cm}$ depth using two passes of a tandem disc harrow across the experimental area (Fig. 1). Common bermudagrass (Cynodon dactylon) and brown top millet (Urochloa ramosa) were seeded in late May 2011 using a Brillion seeder. In 2012, 2013, 2014, and 2015, soil amendment treatments were applied without incorporation using two equal applications of the organic and FGD gypsum amendments in May and August and a single application of inorganic NPK fertilizer in May. Additionally, the rate of FGD gypsum was reduced by $60 \%$ in 2014 , to $4.48 \mathrm{Mg} \mathrm{ha}^{-1}$, due to supply constraints. In 2015 , the rate of FGD gypsum was reduced by $80 \%$, to $2.24 \mathrm{Mg} \mathrm{ha}^{-1}$, and co-applied with the first split-application of poultry litter and swine compost only in June, when the full rate of NPK fertilizer was applied; the subsequent $11.2 \mathrm{Mg} \mathrm{ha}^{-1}$ rate of poultry litter and swine compost was applied to plots in late July.

Table 1. Percent dry matter (DM), nitrate-N, ammonium-N, total C, total N, C:N ratio, and total concentration of other selected nutrients in poultry litter, swine mortality compost, and flue gas desulfurization (FGD) gypsum used as amendments on a newly reclaimed mine soil at Red Hills Mine, Ackerman, MS.

\begin{tabular}{|c|c|c|c|c|c|c|c|c|c|c|c|c|}
\hline Amendment $\dagger$ & $\mathrm{DM}$ & $\mathrm{NO}_{3}$ & $\mathrm{NH}_{4}$ & $\mathrm{C}$ & $\mathrm{N}$ & $\mathrm{C}: \mathrm{N}$ & $\mathrm{P}$ & K & $\mathrm{Ca}$ & $\mathrm{Mg}$ & $\mathrm{Na}$ & $\mathrm{Fe}$ \\
\hline & $\%$ & \multicolumn{11}{|c|}{----------------------------------------- $\mathrm{g} \mathrm{kg}^{-1}$--------------------------------------- } \\
\hline Litter & 81 & 2.7 & 15.6 & 217 & 26.5 & 8.2 & 16.9 & 23.4 & 32.4 & 5.5 & 9.3 & 1.7 \\
\hline Compost & 57 & 0.6 & 2.1 & 263 & 13.7 & 19.2 & 10.7 & 8.1 & 20.2 & 2.9 & 2.8 & 1.8 \\
\hline FGD gypsum & $94 \dagger$ & --- & --- & 0.26 & --- & --- & 0.1 & 0.5 & 152.7 & 0.4 & 0.2 & 0.4 \\
\hline
\end{tabular}

$\dagger$ Poultry litter was obtained from a commercial broiler chicken farm near Macon, MS. Swine mortality compost was obtained from a commercial swine farm near Crawford, MS. FGD gypsum was obtained from Southern Company, Atlanta, GA.

+ Based on reported value of $94.5 \pm 3.0$ for percent dry matter in FGD gypsum (OSU, 2006). 


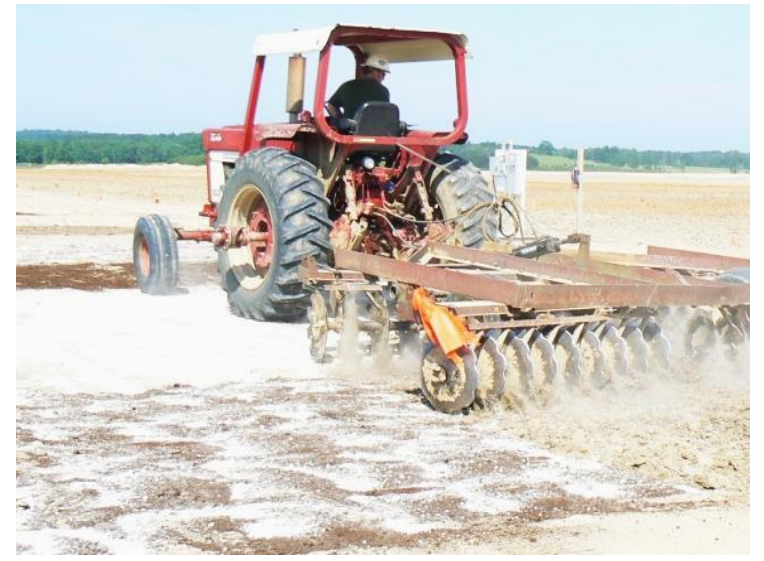

Figure 1. A tandem disc harrow was used to lightly incorporate the soil amendment treatments on 11 May 2011.

Weed control was conducted by applying the post-emergence, broadleaf herbicide Weedmaster in late June 2013 and 2014; dicamba (3,6-dichloro-O-anisic acid) and 2,4-D amine (2,4dichlorophenoxy acetic acid) in this herbicide formulation were applied at rates of $0.14 \mathrm{~kg}$ a.i. $\mathrm{ha}^{-1}$ and $0.40 \mathrm{~kg}$ a.i. ha ${ }^{-1}$, respectively. Based on visual observations in April 2013, the prevalent weed species were common vetch (Vicia angustifolia), slender vetch (Vicia tetraspermum), and mares tail (Conyza canadensis) with lesser amounts of rock goldenrod (Solidago cnadensis) and prickly lettuce (Lactuca scariola).

\section{Chemical and Nutrient Characteristics of Surface and Subsurface Soils}

Soil samples were collected from the 18 experimental plots in December 2011, the first year of treatment application, and in December 2015 after five years of applying soil amendments. Four to five cores were taken at the 0 to $15 \mathrm{~cm}$ and 15 to $30 \mathrm{~cm}$ depths from the central, length-wise portion of each plot in order to avoid cross contamination of materials applied to adjoining plot(s) by dust transfer, as seemed to be the case with disking in 2011 (Fig. 1). The soil cores were mixed thoroughly by depth and placed in a waxed, cardboard box. Samples were air dried in a greenhouse, ground to pass a 2-mm screen, and stored in boxes for chemical analysis. Samples were submitted to the Mississippi State Soil Testing Laboratory for analysis of $\mathrm{pH}$ and soluble salts (using $10 \mathrm{~g}$ soil in $20 \mathrm{ml}$ distilled water), organic matter by oxidation with chromic acid (Walkley, 1947) as modified colorimetrically by DeBolt (1974), and available P, K, Ca, Mg, and $\mathrm{SO}_{4}-\mathrm{S}$ as described by Oldham (2014). Total cation exchange capacity (CEC) was derived from the summation of $\mathrm{H}$, $\mathrm{K}$, Ca, and Mg milliequivalents (meq) and expressed as cmol (+) $\mathrm{kg}^{-1}$ (formerly meq $100 \mathrm{~g}^{-1}$ ). Because using a sum of cations methods is unsuitable when soluble $\mathrm{Ca}$ is elevated from FGD 
gypsum applications, results are presented and discussed for plots not treated with FGD gypsum. The 18 experimental plots also were soil sampled in July 2012, May and November 2013, and May (0 to $15 \mathrm{~cm}$ depth only) and October 2014. Analysis across sampling dates was used to derive any trend or relationship between applied amendments and changes in the soil chemical properties.

Initial soil sampling was conducted on 10 May 2011 (one day prior to soil amendment application) from two plots selected at random in each block $(n=6)$. Results indicated surface 0to $15-\mathrm{cm}$ soil depth had a $\mathrm{pH}$ of $6.62 \pm 0.09$, organic matter of $3.75 \pm 0.56 \mathrm{~g} \mathrm{~kg}^{-1}$, and CEC of $18.4 \pm 0.3 \mathrm{cmol}(+) \mathrm{kg}^{-1}$. Soil P, K, Ca, Mg, and $\mathrm{SO}_{4}-\mathrm{S}$ concentrations were 40, 113, 2009, 859, and $98 \mathrm{mg} \mathrm{kg}^{-1}$, respectively. Subsurface 15 - to $30-\mathrm{cm}$ soil depth had a pH of $6.38 \pm 0.07$, organic matter of $2.28 \pm 0.27 \mathrm{~g} \mathrm{~kg}^{-1}$, and CEC of $18.1 \pm 0.3 \mathrm{cmol}(+) \mathrm{kg}^{-1}$. Soil P, K, Ca, $\mathrm{Mg}_{\text {, and SO}}-\mathrm{S}$ concentrations were $34,102,1865,878$, and $111 \mathrm{mg} \mathrm{kg}^{-1}$, respectively.

\section{$\underline{\text { Bermudagrass Growth and Biomass Yield }}$}

Ground coverage and growth were monitored as the bermudagrass became established in 2011. Visual estimates on 24 June indicated seedlings covered approximately $23 \%$ of the plot area, with the remainder being bare ground. Percent cover was subsequently recorded in nine sub-quadrats $\left(0.04 \mathrm{~m}^{2}\right.$ each) of a $1-\mathrm{m}^{2}$ Providence square on 2 August (Fig. 2). The square was placed at four central, equidistant locations across the length of each plot and the nine values averaged for each location. Bermudagrass vigor was assessed using a 1-10 rating scale and canopy height was determined using a ruler on 19 August and 30 September.

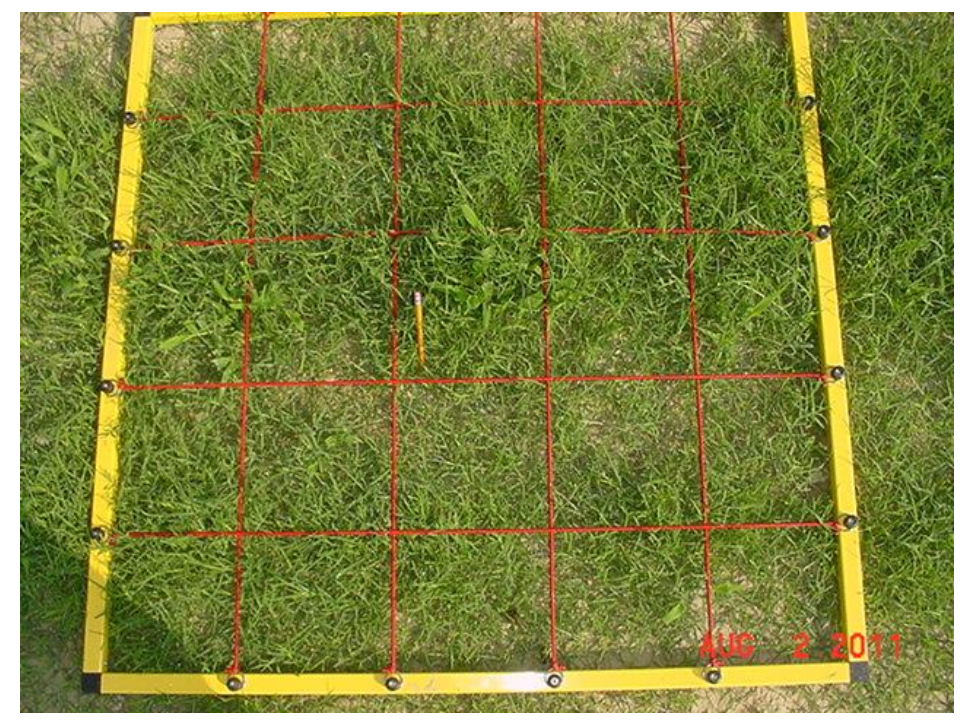

Figure 2. A Providence square was used to visually estimate percent cover of bermudagrass seedlings in 2011. 
Plots were harvested once in the year of establishment, on 30 September 2011, and twice in each of the succeeding three years, on 3 August and 27 September 2012, 2 July and 24 October 2013, and 7 July and 29 September 2014. Forage dry matter (DM) yield was determined by cutting a 0.91 by $12.19 \mathrm{~m}$ swath at a $5 \mathrm{~cm}$ stubble height through the center of each plot using a sickle-bar mower. Subsamples (600-800 g) of forage were dried at $60{ }^{\circ} \mathrm{C}$ for at least $72 \mathrm{~h}$ and the dry weight recorded. The dry forage was ground to pass a $1 \mathrm{~mm}$ screen and sealed in plastic containers. Forage $\mathrm{N}$ concentration was determined in samples from the first harvest date using the ThermoQuest $\mathrm{C} / \mathrm{N}$ analyzer. Yields of DM per plot were calculated and total annual DM was calculated as the sum across all harvests.

\section{$\underline{\text { Pine Tree Response to Fertility Amendments }}$}

A reclamation contractor with Red Hills Mine planted two rows of loblolly pine saplings on the north half of each plot in late winter 2012, giving a total of 4 saplings in each plot $(n=72)$ (Fig. 3). The spacing between rows and plants was $1.8 \mathrm{~m}(6 \mathrm{ft})$. Counts made in September 2013 indicated $33 \%(\mathrm{n}=24)$ survived through summer. A steel tape was used to measure height from ground level to the tallest central candle (Fig. 4). There was one sampling date in 2012, six in 2013, five in 2014, nine in 2015, and seven in 2016. A micrometer (caliper) was used to measure tree diameter approximately $5 \mathrm{~cm}$ from the soil surface in 2015 and 2016.

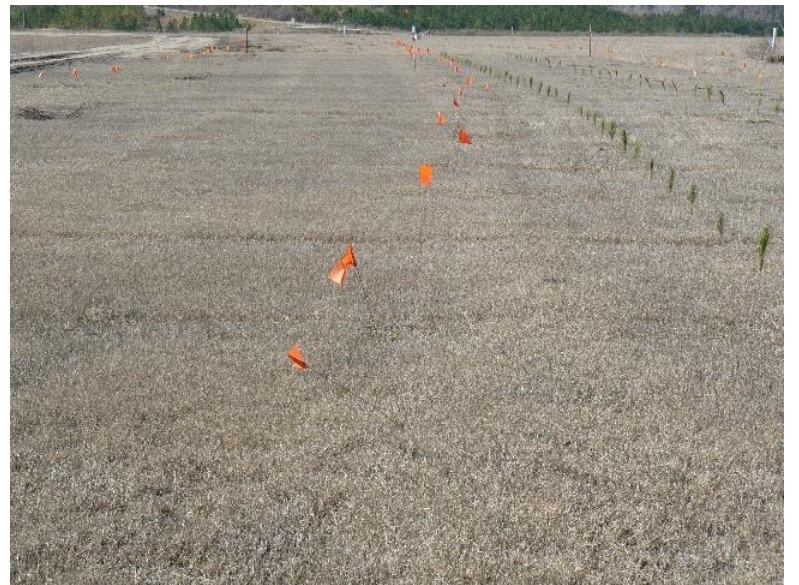

Figure 3. Loblolly pine saplings planted in northern half of the plot area in late winter 2012; approximately $33 \%$ survived through summer.

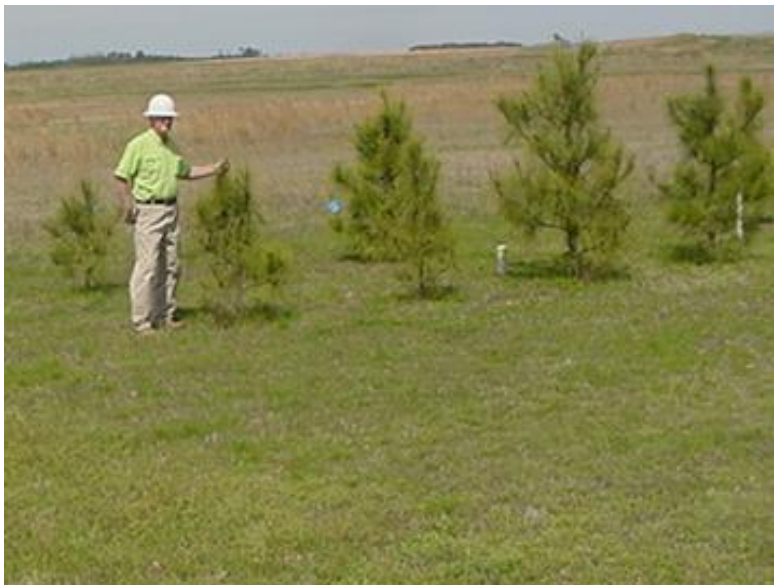

Figure 4. Treatment difference in Loblolly pine health and height four years after planting (17 March 2016). 


\section{Statistical Analysis}

Analysis of treatment effects on soil chemical properties was conducted by sampling date and depth using general linear model (GLM) procedures in SAS (SAS Institute, 2010). The GLM procedures also were used to test treatment effects on bermudagrass performance at different sampling dates in 2011 and the effects of treatment, year, and their interaction on annual DM yield of bermudagrass in 2011 - 2014. Unless otherwise noted, treatment difference was declared significant at the $5 \%$ level of probability. Because tree height each year appeared to reach a peak in September, before resuming growth the following spring, treatment difference was determined based on data from September only. Additionally, the analysis involved soil amendments without FGD gypsum, as the number of trees across these plots was balanced $(n=5)$ enabling individual observations to be used as replicates in the analysis of variance.

\section{$\underline{\text { Results and Discussion }}$}

\section{Chemical and Nutrient Characteristics of Surface and Subsurface Soils}

In surface 0 to $15 \mathrm{~cm}$ soil depth, applying poultry litter for five years increased $\mathrm{pH}$, organic matter, and soil test P, as compared with NPK fertilizer (Table 2). With regard to organic matter concentration in 2015, it was approximately $5.6 \mathrm{~g} \mathrm{~kg}^{-1}$ (or $0.56 \%$ ) greater with poultry litter than NPK fertilizer. Adeli et al. (2017) reported a single application of $13.4 \mathrm{Mg} \mathrm{ha}^{-1}$ poultry litter increased total $\mathrm{C}$ in surface 0 - to $5 \mathrm{~cm}$ soil depth from approximately $3.7 \mathrm{~g} \mathrm{~kg}^{-1}$ to $8.5 \mathrm{~g} \mathrm{~kg}^{-1}$, which represents a $0.96 \%$ increase in the amount of organic matter, assuming the soil organic matter is composed of $50 \%$ total C (Pribyl, 2010). In that study, bermudagrass was grown in a greenhouse for 60 days in intact soil columns $(8 \mathrm{~cm}$ diam. $\times 30-\mathrm{cm}$ height $)$ taken from a respread area nearby the experimental plots used in the present study. They further observed poultry litter increased the percentage of water stable aggregates at 0 to $5 \mathrm{~cm}$ depth in respread soil, as compared to NPK fertilizer (46 vs. 31\%), which is consistent with evidence that soil organic C is involved in the formation of organic binding agents for soil macroaggregation (Zhang, 1994). In surface 0 to $15 \mathrm{~cm}$ soil depth and compared to swine compost and NPK fertilizer amendments, applying poultry litter elevated soil test $\mathrm{K}$ by approximately $44 \mathrm{mg} \mathrm{kg}^{-1}$ in December 2011 (158 vs. $114 \mathrm{mg} \mathrm{kg}^{-1}$ ) and approximately $107 \mathrm{mg} \mathrm{kg}^{-1}$ in December 2015 (276 vs. $169 \mathrm{mg} \mathrm{kg}^{-1}$ ). These responses can be attributed to the relatively greater concentrations of $\mathrm{DM}$, total $\mathrm{P}$, and total $\mathrm{K}$ in poultry litter than swine compost (Table 1); with applications made on an as-is moisture basis, applied total C, P, 
Table 2. Soil pH, soil organic matter (OM), and levels of $\mathrm{P}, \mathrm{K}$, and $\mathrm{SO}_{4}-\mathrm{S}$ at 0 to $15 \mathrm{~cm}$ and 15 to $30 \mathrm{~cm}$ depths in December 2011 and December 2015 in plots receiving annual applications of $22.4 \mathrm{Mg} \mathrm{ha}^{-1}$ poultry litter, $22.4 \mathrm{Mg} \mathrm{ha}^{-1}$ swine compost, and $896 \mathrm{~kg}$ $\mathrm{ha}^{-1}$ 13-13-13 fertilizer without and with the co-application of flue gas desulfurization (FGD) gypsum.

\begin{tabular}{|c|c|c|c|c|c|c|c|c|c|c|}
\hline \multirow{2}{*}{$\begin{array}{l}\text { Depth and } \\
\text { amendment }\end{array}$} & \multicolumn{2}{|c|}{$\mathrm{pH}$} & \multicolumn{2}{|c|}{$\mathrm{OM}$} & \multicolumn{2}{|c|}{$\mathrm{P}$} & \multicolumn{2}{|c|}{$\mathrm{K}$} & \multicolumn{2}{|c|}{$\mathrm{SO}_{4}-\mathrm{S}$} \\
\hline & 2011 & 2015 & 2011 & 2015 & 2011 & 2015 & 2011 & 2015 & 2011 & 2015 \\
\hline 0 to $15 \mathrm{~cm}$ & & & \multicolumn{2}{|c|}{---- g kg $^{-1}$} & ------- & ------ & - m & -1 ----- & & ------- \\
\hline Litter $\uparrow$ & 6.1 & $6.9 \mathrm{a} \ddagger$ & $3.43 \mathrm{~b}$ & $14.17 \mathrm{a}$ & $105 \mathrm{ab}$ & $221 \mathrm{a}$ & $153 \mathrm{a}$ & $242 a b$ & $42 \mathrm{~b}$ & 20 \\
\hline Litter + FGD & 6.2 & $7.0 \mathrm{a}$ & $5.83 \mathrm{a}$ & $10.67 \mathrm{~b}$ & $121 \mathrm{a}$ & $184 \mathrm{~b}$ & $164 \mathrm{a}$ & $310 \mathrm{a}$ & $1205 \mathrm{a}$ & 59 \\
\hline Compost & 6.3 & $6.6 \mathrm{ab}$ & $5.97 \mathrm{a}$ & $9.63 \mathrm{bc}$ & $118 \mathrm{a}$ & $115 \mathrm{c}$ & $119 \mathrm{~b}$ & $173 \mathrm{~b}$ & $80 \mathrm{~b}$ & 18 \\
\hline Compost + FGD & 6.0 & $6.5 \mathrm{ab}$ & $6.10 \mathrm{a}$ & $9.10 \mathrm{bc}$ & $68 \mathrm{bc}$ & $101 \mathrm{~cd}$ & $116 \mathrm{~b}$ & $170 \mathrm{~b}$ & $985 \mathrm{a}$ & 71 \\
\hline Fertilizer & 6.2 & $6.1 \mathrm{~b}$ & $4.70 \mathrm{ab}$ & $7.23 \mathrm{c}$ & $48 \mathrm{c}$ & $74 \mathrm{~d}$ & $109 \mathrm{~b}$ & $172 \mathrm{~b}$ & $50 \mathrm{~b}$ & 16 \\
\hline Fertilizer + FGD & 6.1 & $6.2 \mathrm{~b}$ & $4.70 \mathrm{ab}$ & $6.43 \mathrm{c}$ & $56 \mathrm{c}$ & $79 \mathrm{~d}$ & $111 \mathrm{~b}$ & $162 \mathrm{~b}$ & $1019 \mathrm{a}$ & 58 \\
\hline $5 \% \mathrm{LSD} \S$ & 0.5 & 0.5 & 1.77 & 3.00 & 44 & 29 & 27 & 78 & 584 & 58 \\
\hline \multicolumn{11}{|l|}{15 to $30 \mathrm{~cm}$} \\
\hline Litter† & 5.9 & 6.4 & 2.97 & 5.20 & 46 & 53 & 102 & 154 & $137 \mathrm{~b}$ & $41 \mathrm{~b}$ \\
\hline Litter + FGD & 6.0 & 6.1 & 3.73 & 5.63 & 38 & 48 & 115 & 132 & $323 a$ & $170 \mathrm{ab}$ \\
\hline Compost & 5.8 & 6.0 & 4.23 & 6.60 & 40 & 44 & 101 & 135 & $156 \mathrm{~b}$ & $81 \mathrm{~b}$ \\
\hline Compost + FGD & 5.8 & 5.1 & 3.77 & 4.57 & 41 & 49 & 106 & 138 & $348 \mathrm{a}$ & $245 \mathrm{a}$ \\
\hline Fertilizer & 6.0 & 5.8 & 4.20 & 6.40 & 40 & 47 & 104 & 120 & $127 \mathrm{~b}$ & $72 \mathrm{~b}$ \\
\hline Fertilizer + FGD & 5.9 & 5.9 & 3.97 & 3.73 & 36 & 47 & 99 & 132 & $351 \mathrm{a}$ & $135 \mathrm{ab}$ \\
\hline $5 \% \mathrm{LSD}$ & 0.4 & 0.8 & 2.45 & 3.44 & 9 & 14 & 17 & 26 & 55 & 119 \\
\hline
\end{tabular}

$\uparrow$ Organic amendments were provided as a single application and incorporated in 2011 and as two equally split applications without incorporation in 2012, 2013, 2014, and 2015. Inorganic NPK fertilizer was provided as a single application in May $2011-2014$ and in June 2015. The rate of FGD gypsum was $11.2 \mathrm{Mg} \mathrm{ha}^{-1}$ in $2011-2013,4.48 \mathrm{Mg} \mathrm{ha}^{-1}$ in 2014, and 2.24 Mg ha ${ }^{-1}$ in 2015.

+ Within a sampling year and soil depth, means followed by a different letter are significantly different according to Fisher's protected Duncan's multiple range test $(\mathrm{P}<0.05)$; otherwise, not significant.

$\S$ Least significant difference at the $5 \%$ level of probability. 
and $\mathrm{K}$ are much greater for poultry litter. In subsurface 15 to $30 \mathrm{~cm}$ soil depth, $\mathrm{pH}$, organic matter, and available $\mathrm{P}$ and $\mathrm{K}$ levels did not differ among amendment treatments (Table 2).

At the end of the study, the co-application of FGD gypsum with poultry litter, swine compost, and NPK fertilizer decreased soil organic matter in surface soil by approximately 33, 6, and 12\%, respectively (Table 2). Additionally, for plots with no history of FGD gypsum, the increase in soil organic matter across the two sampling dates ranged from 54 to $313 \%$ in surface soil and from 37 to $83 \%$ in subsurface soil, depending on fertility amendment; the largest change was observed in plots amended with poultry litter. In contrast, a short-term study (Adeli et al., 2017) lasting 60 days found total $\mathrm{C}$ concentration at 0 - to $5-\mathrm{cm}$ soil depth was similar between poultry litter only and poultry litter mixed with $2.86 \mathrm{Mg} \mathrm{ha}^{-1}$ FGD gypsum (8.5 vs. $8.1 \mathrm{~g} \mathrm{~kg}^{-1}$ ).

As expected, soils analysis in December 2011 indicated the co-application of FGD gypsum in May 2011 elevated $\mathrm{SO}_{4}-\mathrm{S}$ levels in the surface and subsurface soils (Table 2). The increase in $\mathrm{SO}_{4}-\mathrm{S}$ concentration with FGD gypsum was approximately 913 and $201 \mathrm{mg} \mathrm{kg}^{-1}$ in surface and subsurface soils, respectively, as compared to untreated plots that had $\mathrm{SO}_{4}-\mathrm{S}$ values similar to those found one day prior to the first soil amendment application. Lang and Crouse (2017) reported that soluble salts are an indicator of $\mathrm{SO}_{4}-\mathrm{S}$ in reclaimed coal mine soil, though soluble salts may also increase as soil fertility increases. Consistent with that report, when data from December 2011 were averaged across fertility amendment treatments, the co-application of FGD gypsum increased soluble salts in surface soil from approximately 0.21 to $1.71 \mathrm{dS} \mathrm{m}^{-1}$ and in subsurface soil from 0.42 to $0.74 \mathrm{dS} \mathrm{m}^{-1}$ (data not presented). The FGD gypsum effect on soluble salts was significant at both sampling depths $(\mathrm{P}<0.01)$ without a significant gypsum $\mathrm{x}$ fertility amendment interaction (P > 0.90). Analysis of surface 0 to $15 \mathrm{~cm}$ soil depth in December 2015 indicated no difference among amendment treatments in $\mathrm{SO}_{4}-\mathrm{S}(\mathrm{P}>0.18)$ and soluble salts $(\mathrm{P}>0.07)$ (Table 2). This probably resulted from reductions in FGD gypsum application rates in 2014 and 2015 as well as apparent leaching of salts to deeper depths, as elevated levels of $\mathrm{SO}_{4}-\mathrm{S}$ and soluble salts were detected at 15 to $30 \mathrm{~cm}$ soil depth in plots with a 5-year history of FGD gypsum application $(\mathrm{P}<0.05)$. Lang and Crouse (2017) concluded extractable $\mathrm{SO}_{4}-\mathrm{S}$ can be used as an initial indicator for pyritic-S in overburden materials mined for lignite at Red Hills Mine; an overburden testing high in pyritic-S (500 to $1000 \mathrm{mg} \mathrm{kg}^{-1} \mathrm{SO}_{4}-\mathrm{S}$ ) is considered unsuitable as a topsoil substitute due to increased potential acidity. In the present study, soils with no history of FGD gypsum had $\mathrm{SO}_{4}$ $\mathrm{S}$ values that ranged from 16 to $173 \mathrm{mg} \mathrm{kg}^{2}$, depending on year and sampling depth. Because 
extractable sulfate in normal agricultural soils can range from 50 to $200 \mathrm{mg} \mathrm{kg}^{-1}$ depending upon seasonal S mineralization stages, results of the present study indicate the overburden materials used for respread soil contained little pyritic-S.

Cation exchange capacity represents the amount of exchange sites, chiefly on clay minerals and organic matter, that can adsorb and release cations (Pierzynski et al., 2000). The cations used by plants in the largest amounts are $\mathrm{K}, \mathrm{Ca}$, and $\mathrm{Mg}$. By cation exchange, hydrogen ions from the root hairs and soil microorganisms replace the adsorbed/absorbed nutrient cations. Total CEC as found in the present study (using $\mathrm{pH}$ and Lancaster method of available nutrient assessment) was used as a surrogate for fertility status of the surface 0 - to $15-\mathrm{cm}$ soil depth only in plots with no history of FGD gypsum. Increasing trends were observed from December 2011 to July 2012 and from May 2014 to December 2015, with steady or declining trend in the intervening sampling dates (data not presented). A slight $(\mathrm{P}<0.10)$ treatment effect on CEC was detected in December 2015, when values were approximately $22.9,21.4$, and $20.2 \mathrm{cmol}(+) \mathrm{kg}^{-1}$ with poultry litter, swine compost, and NPK fertilizer amendments, respectively; otherwise treatments did not differ significantly $(\mathrm{P}>0.29)$. In general, $\mathrm{CEC}$ values were somewhat greater with the two organic amendments than NPK fertilizer, probably owing to repeated applications of nutrient cations and $\mathrm{C}$ to the soil (Table 1). Apparently, CEC was responsive to the additions of organic matter materials that can have a 4 to 50 times higher CEC per given weight than clay minerals (Pierzynski et al., 2000). In studies on reclaimed coal mine soils in Indonesia, Noviyanto et al. (2017) reported CEC and total $\mathrm{N}$ were the main indicators of soil quality for sites after 1,15 , and 18 years of land reclamation. Soils in the 15-year old reclamation and natural forest areas had statistically similar CEC (28.2 vs. $25.8 \mathrm{cmol}(+) \mathrm{kg}^{-1}$ ) and CEC was significantly less in both the 1-year old $\left(19.9 \mathrm{cmol}(+) \mathrm{kg}^{-1}\right)$ and 15-year old $\left(22.2 \mathrm{cmol}(+) \mathrm{kg}^{-1}\right)$ land reclamation areas. In the present study, total CEC of the surface soil at all sampling dates after 2011 exceeded the initial level of $18.4 \pm 0.3 \mathrm{cmol}(+) \mathrm{kg}^{-1}$ by 0.43 to $4.51 \mathrm{cmol}(+) \mathrm{kg}^{-1}$ in plots amended with poultry litter and by 0.82 to $2.96 \mathrm{cmol}(+) \mathrm{kg}^{-1}$ in plots amended with swine compost. A wide range of increase in total CEC across sampling dates may be due to fast release of nutrient cations or application timing relative to significant rain events, not to mention methodology accuracy and precision errors in assessment of the soil cations, $\mathrm{H}, \mathrm{K}, \mathrm{Ca}$, and $\mathrm{Mg}$.

\section{Bermudagrass Growth and Biomass Yield}

Percent bermudagrass cover in August 2011 did not differ among soil amendment treatments 
and ranged from approximately $77 \%$ with swine mortality compost to $90 \%$ with NPK fertilizer (Table 3). Percent cover was not affected by the co-application of FGD gypsum. Apparently, amending the respread soil with either $22.4 \mathrm{Mg} \mathrm{ha}^{-1}$ poultry litter or swine compost in May 2011 prior to planting did not improve the rate of seedling establishment. But applying poultry litter

Table 3. Bermudagrass percent cover on 2 August 2011, vigor rating (1-10 scale) on 19 August and 30 September 2011, and canopy height on 19 August and 30 September 2011 in plots receiving a single application of $22.4 \mathrm{Mg} \mathrm{ha}^{-1}$ poultry litter, $22.4 \mathrm{Mg} \mathrm{ha}^{-1}$ swine compost, and $896 \mathrm{~kg} \mathrm{ha}^{-1} 13-13-13$ fertilizer in May 2011 without and with the coapplication of flue gas desulfurization (FGD) gypsum.

\begin{tabular}{|c|c|c|c|c|c|}
\hline \multirow[b]{2}{*}{ Amendment } & \multirow{2}{*}{$\frac{\text { Cover }}{2 \mathrm{Aug}}$} & \multicolumn{2}{|c|}{ Vigor } & \multicolumn{2}{|c|}{ Canopy height } \\
\hline & & 19 Aug & 30 Sep & 19 Aug & $30 \mathrm{Sep}$ \\
\hline & $\%$ & & & \multicolumn{2}{|c|}{--------- cm --------- } \\
\hline Litter & 83 & 7.7 & $8.0 \mathrm{a} \dagger$ & $16.1 \mathrm{ab}$ & $21.1 \mathrm{a}$ \\
\hline Litter + FGD & 86 & 8.3 & $6.0 \mathrm{~b}$ & $17.8 \mathrm{a}$ & $20.8 \mathrm{a}$ \\
\hline Compost & 78 & 4.0 & $3.3 \mathrm{c}$ & $13.8 \mathrm{bc}$ & $17.0 \mathrm{~b}$ \\
\hline Compost + FGD & 76 & 3.7 & $3.7 \mathrm{c}$ & $12.2 \mathrm{c}$ & $15.9 \mathrm{~b}$ \\
\hline Fertilizer & 91 & 6.0 & $3.7 \mathrm{c}$ & $15.8 \mathrm{ab}$ & $18.2 \mathrm{ab}$ \\
\hline Fertilizer + FGD & 90 & 7.7 & $4.3 \mathrm{c}$ & $13.6 \mathrm{bc}$ & $16.2 \mathrm{~b}$ \\
\hline $5 \%$ LSD & 33 & 3.6 & 1.4 & 2.9 & 2.9 \\
\hline
\end{tabular}

$\dagger$ Within a column, means followed by a different letter are significantly different according to Fisher's protected Duncan's multiple range test $(\mathrm{P}<0.05)$; otherwise, not significant.

+ Least significant difference at the $5 \%$ level of probability.

generally improved bermudagrass performance as the plants became established, as vigor rating differed slightly among treatments on 19 August $(\mathrm{P}>0.06)$ and bermudagrass vigor and canopy height were significantly greater with poultry litter than swine compost on 30 September. On this sampling date, canopy height and DM yield (Table 4) were similar for plots provided NPK fertilizer only and plots provided poultry litter with or without FGD gypsum. Apparently, bermudagrass $\mathrm{N}$ demand in the year of establishment was met by fertilizer $\mathrm{N}$ even though the rate of inorganic $\mathrm{N}\left(\mathrm{NO}_{3}-\mathrm{N}+\mathrm{NH}_{4}-\mathrm{N}\right)$ applied and incorporated to $15 \mathrm{~cm}$ soil depth (Fig. 1) was nearly three orders of magnitude less than the rate applied with poultry litter (116 vs. $\left.332 \mathrm{~kg} \mathrm{ha}^{-1}\right)$. This response can be credited to the additional $\mathrm{N}, \mathrm{P}$, and $\mathrm{K}$ in poultry litter, as well as more $\mathrm{C}$ due to high dry matter (of which, approximately $35 \%$ is C) (Table 1) and perhaps improved soil moisture in these typically droughty months. The standard reclamation practice of $896 \mathrm{~kg} \mathrm{ha}^{-1} \mathrm{NPK}$ fertilizer provides no organic matter, which may explain the decrease in plant vigor in 2011. Bermudagrass vigor on 30 September was affected by a fertility amendment x FGD gypsum 
interaction $(\mathrm{P}<0.05)$, probably because co-application of FGD gypsum with poultry litter decreased vigor by approximately 2 units and co-application with either swine compost or NPK fertilizer increased vigor by 0.5 units.

Annual DM yield was affected by soil amendment, year, and their interaction (Table 4). In general, the ranking of annual DM yield was poultry litter $>$ NPK fertilizer $=$ swine compost. Annual average DM generally increased across years and was greatest in 2013. As compared to applying $896 \mathrm{~kg} \mathrm{ha}^{-1}$ fertilizer, $22.4 \mathrm{Mg} \mathrm{ha}^{-1}$ poultry litter increased annual DM yield by approximately 1172 to $4396 \mathrm{~kg} \mathrm{ha}^{-1}$ depending on year (3908 $\mathrm{kg} \mathrm{ha}^{-1}$ on average). Co-application of FGD gypsum with poultry litter decreased DM yield in 2012 and increased DM yield in 2014; otherwise, the FGD gypsum effect was not significant. When data were averaged across fertility amendments and years, DM yield was not affected by FGD gypsum ( $>$ > 0.16) and was approximately $4944 \mathrm{~kg} \mathrm{ha}^{-1}$ with co-application of FGD gypsum and $4587 \mathrm{~kg} \mathrm{ha}^{-1}$ without coapplication of FGD gypsum.

Table 4. Annual bermudagrass dry matter yield in plots harvested once in 2011 (the establishment year) and twice in 2012, 2013, and 2014 that received annual applications of $22.4 \mathrm{Mg}$ $\mathrm{ha}^{-1}$ poultry litter, $22.4 \mathrm{Mg} \mathrm{ha}^{-1}$ swine compost, and $896 \mathrm{~kg} \mathrm{ha}^{-1} 13-13-13$ fertilizer without and with the co-application of flue gas desulfurization (FGD) gypsum.

\begin{tabular}{|c|c|c|c|c|c|}
\hline Amendment & 2011 & 2012 & 2013 & 2014 & Mean \\
\hline & ----------- & - & $\mathrm{kg} \mathrm{ha}^{-1}$ & & 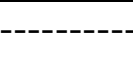 \\
\hline Litter $\dagger$ & $3723 a t$ & $7401 \mathrm{a}$ & $8799 a$ & $7902 \mathrm{~b}$ & $6956 a$ \\
\hline Litter + FGD & $4114 \mathrm{a}$ & $6540 \mathrm{~b}$ & $9475 \mathrm{a}$ & $10083 \mathrm{a}$ & $7553 \mathrm{a}$ \\
\hline Compost & $2008 \mathrm{c}$ & $1982 \mathrm{c}$ & $5312 b$ & $3773 \mathrm{c}$ & $3536 \mathrm{~b}$ \\
\hline Compost + FGD & $1860 \mathrm{c}$ & $1990 \mathrm{c}$ & $5997 \mathrm{~b}$ & $3846 \mathrm{c}$ & $3856 \mathrm{~b}$ \\
\hline Fertilizer & $3023 \mathrm{abc}$ & $2378 \mathrm{c}$ & $4944 \mathrm{~b}$ & $3803 \mathrm{c}$ & $3269 \mathrm{~b}$ \\
\hline Fertilizer + FGD & $2470 \mathrm{bc}$ & $2478 \mathrm{c}$ & $5087 \mathrm{~b}$ & $5390 \mathrm{c}$ & $3423 \mathrm{~b}$ \\
\hline Mean§ & $2866 \mathrm{D}$ & $3795 \mathrm{C}$ & $6602 \mathrm{~A}$ & $5799 \mathrm{~B}$ & \\
\hline
\end{tabular}

$\uparrow$ Organic amendments were provided as a single application and incorporated in 2011 and as two equally split applications without incorporation in 2012, 2013, 2014, and 2015. Inorganic NPK fertilizer was provided as a single application in May $2011-2014$. The rate of FGD gypsum was $11.2 \mathrm{Mg} \mathrm{ha}^{-1}$ in 2011 - 2013 and $4.48 \mathrm{Mg} \mathrm{ha}^{-1}$ in 2014.

+ Within a column, means followed by a different lowercase letter are significantly different according to Fisher's protected Duncan's multiple range test $(\mathrm{P}<0.05)$.

$\S$ Within a row, means followed by a different uppercase letter are significantly different according to Fisher's protected least significant difference $(\mathrm{P}<0.05)$.

High biomass yield in poultry litter treatments may be explained by a two-fold greater total $\mathrm{N}$ concentration in poultry litter than swine mortality compost (26.5 vs $\left.13.7 \mathrm{~g} \mathrm{~kg}^{-1}\right)$. In the year of 
application, approximately 50 to $60 \%$ of the total $\mathrm{N}$ applied in poultry litter is mineralized and becomes plant available (Read et al., 2018). This suggests that litter provided approximately 240 to $288 \mathrm{~kg} \mathrm{ha}^{-1}$ total $\mathrm{N}$ in 2011 , with any residual (carryover) $\mathrm{N}$ in the soil providing additional 'mineralizable' $\mathrm{N}$ in subsequent years. The recommended rate of fertilizer $\mathrm{N}$ for hybrid bermudagrass production in Mississippi is about $270 \mathrm{~kg} \mathrm{ha}^{-1} \mathrm{yr}^{-1}$ ( $\operatorname{Read}$ et al., 2006). The C:N ratio was approximately two times greater in swine compost than poultry litter (19 vs. 8) (Table 1), but neither $C: N$ ratio exceeded 20:1, considered to be the 'threshold' $C: N$ ratio above which $N$ immobilization is likely to occur (Cooperband et al., 2002). So, while both of the organic materials had favorable $\mathrm{C}: \mathrm{N}$ ratio for $\mathrm{N}$ mineralization, poultry litter had greater initial $\mathrm{NO}_{3}-\mathrm{N}$ content and appeared to be a better source for the transfer of $\mathrm{N}$ in this reclaimed soil and its availability to bermudagrass. This notion is supported from analysis of forage $\mathrm{N}$ concentration (data not presented). When data were averaged across years, forage $\mathrm{N}$ was greater with poultry litter than either swine compost or NPK fertilizer amendment (129 vs. 105 vs. $90 \mathrm{~g} \mathrm{~kg}^{-1}$; LSD = $11 \mathrm{~g} \mathrm{~kg}^{-1}$ ). These observations agree with Adeli et al. (2017) who reported leachate $\mathrm{NO}_{3}-\mathrm{N}$ content (or the mass loss) from this respread soil planted to bermudagrass was significantly greater with fresh (uncomposted) than with composted poultry litter (9.4 vs. $6.6 \mathrm{~kg} \mathrm{ha}^{-1}$, average of five weekly leaching events) that were applied to the soil surface at nearly equivalent total $\mathrm{N}$ rates of 415 and $390 \mathrm{~kg} \mathrm{ha}^{-1}$, respectively. The process of composting swine mortalities can stabilize $\mathrm{N}$, as Amlinger et al. (2003) found that composting original feedstock materials (poultry litter) transformed labile $\mathrm{N}$ compounds into more recalcitrant $\mathrm{N}$ compounds.

Based on soil analysis in December 2011, available P and K concentrations at 0 to $30 \mathrm{~cm}$ depth were similar in the poultry litter and swine compost treatments $(\mathrm{P}>0.34)$. Additionally, levels of $\mathrm{P}$ and $\mathrm{K}$ in all treatments were generally adequate for optimal growth of warm-season forages (SERA IEG 6, 2009).

Diacono and Montemurro (2010) reported that application of poultry litter to a degraded (agricultural) soil increased crop yield by $250 \%$, as compared with inorganic fertilizer. The beneficial effects of poultry litter on crop yield could be related to remediation of soil quality in respread soil. Repeatedly applying poultry litter that contained approximately $217 \mathrm{~g} \mathrm{~kg}^{-1}$ total C and had a relatively low $\mathrm{C}: \mathrm{N}$ ratio of 8.2, as compared with 19.2 in swine compost (Table 1), has the potential to increase levels of soil organic C. Other studies have demonstrated soil organic C acts as a binding agent and can strongly affect a number of soil quality factors, including nutrient 
cycling, hydrology, and microbial activity (Haynes and Naidu, 1998; Hearing et al., 2000). Kingery et al. (1994) reported long-term application of broiler litter to tall fescue (Schedonorus arundinaceus) resulted in greater soil organic $\mathrm{C}$ concentration at 0 to $15 \mathrm{~cm}$ depth. In a $2-\mathrm{yr}$ study on soil with a 30+ year history of poultry litter, Sistani et al. (2004) reported application of 13.75 $\mathrm{Mg} \mathrm{ha}^{-1} \mathrm{yr}^{-1}$ poultry litter to forage bermudagrass increased soil total $\mathrm{C}$ from approximately 11 to $18 \mathrm{~g} \mathrm{~kg}^{-1}$ at 0 to $10 \mathrm{~cm}$ depth.

\section{$\underline{\text { Pine Tree Response to Fertility Amendment }}$}

As compared to annual NPK fertilization, tree height of poultry litter-amended plots was approximately 37 and 38\% greater in September 2015 and 2016, respectively, and for swine compost-amended plots was 21 and 15\% greater, respectively (Table 5). The height/diameter ratio was least with poultry litter $(\mathrm{P}<0.10)$, suggesting these trees have improved stability, that is, a lower position of center of gravity. Based on data collected in September, the 1-yr diameter increment increased from $2.11 \mathrm{~cm}$ in control plots provided with NPK fertilizer to $2.31 \mathrm{~cm}$ in swine compost plots and $2.93 \mathrm{~cm}$ in poultry litter plots, which represents a 9 and $39 \%$ increase in growth rate, respectively. This result is consistent with Friend et al. (2006) who observed a 53\% increase in growth rate (2-yr diameter increment) as compared with unfertilized loblolly pine when a 10-yr-old stand was provided a single application of $4.6 \mathrm{Mg} \mathrm{ha}^{-1}$ poultry litter. Given the small sample size in the present study $(n=5)$, the data collected are not conclusive enough to state that poultry litter, swine compost, and NPK fertilizer did not have any beneficial effects on pine growth parameters, nor do they negatively impact them. Soil porosity, rainfall intensity, time between rainfall events, mineralization of applied $\mathrm{N}$ and $\mathrm{P}$, and nutrient uptake can all have an effect on loblolly pine establishment and growth, and therefore, it is difficult to make a broad recommendation based on these study results.

Table 5. Loblolly pine height in September 2013 - 2016 and height:diameter ratio in September 2015 and 2016 for trees receiving annual applications of $22.4 \mathrm{Mg} \mathrm{ha}^{-1}$ poultry litter, 22.4 $\mathrm{Mg} \mathrm{ha}^{-1}$ swine mortality compost, and $896 \mathrm{~kg} \mathrm{ha}^{-1}$ NPK fertilizer (as 13-13-13) in 2012 -2015 . Saplings were planted in late winter 2012.

\begin{tabular}{|c|c|c|c|c|c|c|}
\hline \multirow[b]{2}{*}{ Amendment } & \multicolumn{4}{|c|}{ Height } & \multicolumn{2}{|c|}{ Height:diameter ratio } \\
\hline & 2013 & 2014 & 2015 & 2016 & 2015 & 2016 \\
\hline & \multicolumn{4}{|c|}{-------------------------- cm ------------------------- } & \multicolumn{2}{|c|}{---------- $\mathrm{cm} \mathrm{mm}^{-1}$} \\
\hline Litte & $61 \pm 8 \dagger$ & $131 \pm 25$ & $194 \pm 15$ & $313 \pm 35$ & $2.97 \pm 0.27$ & $3.29 \pm 0.34$ \\
\hline Compost & $62 \pm 22$ & $111 \pm 44$ & $171 \pm 36$ & $262 \pm 41$ & $3.29 \pm 0.32$ & $3.47 \pm 0.17$ \\
\hline Fertilizer & $50 \pm 16$ & $87 \pm 23$ & $141 \pm 45$ & $227 \pm 72$ & $3.03 \pm 0.32$ & $3.34 \pm 0.27$ \\
\hline
\end{tabular}

$\dagger$ Mean \pm one standard deviation of the mean $(n=5)$. 


\section{Conclusions}

Reclamation of disturbed (respread) soil at a surface coal mine in northeast Mississippi using poultry litter was successful. Vegetation was established and soil fertility was improved. Soil $\mathrm{pH}$ was raised slightly compared with the standard practice of NPK fertilization. In the five years after planting, loblolly pine growth parameters were improved. The co-application of FGD gypsum with poultry litter for five years significantly decreased organic matter concentration in the 0 to $15 \mathrm{~cm}$ soil depth; otherwise, results for FGD gypsum were inconclusive. As compared to annual NPK fertilization, loblolly pine height was greater by 22 to $39 \%$, depending on year, for plots amended with organic materials, poultry litter, or swine mortality compost. Consistently greater forage biomass production in 2012-2014 with poultry litter applications than with applications of swine compost is attributed to substantially more available $\mathrm{N}$, as well as $\mathrm{P}$ and $\mathrm{K}$ in poultry litter (Table 1). Similar to poultry litter, soil P level was greater with swine mortality compost than NPK fertilization after applying treatments for five years. But unlike poultry litter, the swine compost amendment did not appear to be a viable option to enhance soil organic matter and bermudagrass productivity as compared with applying NPK fertilizer each year.

\section{$\underline{\text { Literature Cited }}$}

Adeli, A., J.J. Read, G.G. Feng, N.R. McGrew, and J.N. Jenkins. 2017. Organic amendments and nutrient leaching in soil columns. Agron. J. 109:1294-1302.

\section{https://doi.org/10.2134/agronj2016.11.0634}

Amlinger, F., B. Gotz, P. Dreher, J. Geszti, and C. Weissteiner. 2003. Nitrogen in biowaste and yard waste compost: Dynamics of mobilization and availability: A review. Eur. J. Soil Biol. 39:107-116. https://doi.org/10.1016/S1164-5563(03)00026-8

Bendfeldt, E.S., J.A. Burger, and W.L. Daniels. 2001. Quality of amended mine soils after sixteen years. Soil Sci. Soc. Am. J. 65:1736-44. https://doi.org/10.2136/sssaj2001.1736

Boerner R.E.J, A.J. Scherzer, and J.A. Brinkman. 1998. Spatial patterns of inorganic N, P availability, and organic $\mathrm{C}$ in relation to soil disturbance: A chronosequence analysis. Appl. Soil Ecol. 7:159-177. https://doi.org/10.1016/S0929-1393(97)00037-1

Chatterjee, A., R. Lal, R.K. Shrestha, and D.A.N. Ussiri. 2009. Soil carbon pools of reclaimed mine soils under grass and forest land uses. Land Degrad. Dev. 20:300-307. https://doi.org/10.1002/ldr.916 
Cooperband, L., G. Bollero, and F. Coale. 2002. Effect of poultry litter and composts on soil nitrogen and phosphorus availability and corn production. Nutr. Cycl. Agroecosys. 62:185194. https://doi.org/10.1023/A:1015538823174

Coyne M.S., Q. Zhai, C.T. Mackown, and R.I. Barnhisel. 1998. Gross nitrogen transformation rates in soil at a surface coal mine site reclaimed for prime farmland use. Soil Biol Biochem. 30:1099-1106. https://doi.org/10.1016/S0038-0717(97)00202-2

DeBolt, D.C. 1974. A simple volume procedure for the colorimetric determination of soil organic matter. Comm. Soil Sci. Plant Anal. 5:131-137. https://doi.org/10.1080/00103627409366489

Diacono, M. and F. Montemurro. 2010. Long-term effects of organic amendments on soil fertility: A review. Agron. Sustain. Dev. 30:401-422. https://doi.org/10.1051/agro/2009040

Edwards, D.R. and T.C. Daniel. 1992. Environmental impacts of on-farm poultry water disposal: A review. Bioresource Tech. 41:9-33. https://doi.org/10.1016/0960-8524(92)90094-E

Evanylo, G., C. Sherony, J. Spargo, D. Starner, M. Brosius, and K. Haering. 2008. Soil and water environmental effects of fertilizer-, manure-, and compost-based fertility practices in an organic vegetable cropping system. Agric. Ecosys. Environ.127:50-58. https://doi.org/10.1016/j.agee.2008.02.014

Friend A.L., S.D. Roberts, S.H. Schoenholtz, J.A. Mobley, and P.D. Gerard. 2006. Poultry litter application to loblolly pine forests: growth and nutrient containment. Journal of Environmental Quality 35:837-848. DOI:10.2134/jeq2005.0244. https://doi.org/10.2134/jeq2005.0244

Haynes, R.J. and R. Naidu. 1998. Influence of lime, fertilizer and manure applications on soil organic matter content and soil physical conditions: A review. Nutr. Cycl. Agroecosys. 51:123137. https://doi.org/10.1023/A:1009738307837

Hearing K.C., W.L. Daniels, and S.E. Feagley. 2000. Reclaiming mined lands with biosolids, manures, and papermill sludges. p. 615-644. In R.I. Barnhisel et al. (ed.) Reclamation of drastically disturbed lands. Agronomy, ASA, CSSA, SSSA, Madison, WI.

Kingery, W.L., J.C. Williams, G.L. Mullins, C.W. Wood, and D.P. Delaney. 1994. Impact of longterm land application of broiler litter on environmentally related soil properties. J. Environ. Qual. 23:139-147. https://doi.org/10.2134/jeq1994.00472425002300010022x

Lang, D.J. and K.K. Crouse. 2017. Utilization of extractable soil test sulfate as an indicator for acid producing pyritic sulfur. In R.I. Barnhisel (ed.) Proceedings 34th Annual Meetings of 
the American Society of Mining and Reclamation, (Morgantown, WV, April 9-13, 2017), American Society of Mining and Reclamation, Lexington, KY. https://www.asmr.us/Portals/0/Documents/Meetings/2017/04-04-Lang-Slides.pdf

Lang, D.J., G. Hawkey, and B. Chow. 2005. Productivity of reclaimed soil at the Red Hills Lignite Mine in Ackerman, MS. 2005. In R.I. Barnhisel (ed.) Proceedings 22nd Annual Meetings of the American Society of Mining and Reclamation, 22:667-677. (Breckenridge, CO, June 1923, 2005), American Society of Mining and Reclamation, Lexington, KY. http://doi.org/10.21000/JASMR05010667

Lang, D.J., G. Hawkey, B. Chow, and V. Maddox. 2006. Revegetation success at the Red Hills Lignite Mine in Mississippi. In R.I. Barnhisel (ed.) Proceedings 10th Billings Land Reclamation Symposium, 10:421-430. (Billings, MT, June 4-8, 2006). Billings Land Reclamation Symposium and American Society of Mining and Reclamation, Lexington, KY. http://doi.org/10.21000/JASMR06010421

Lang, D., B. Shankle, V. Temu, J. Sanborn, and G. Hawkey. 2008. Characterization of deep subsoil strata as suitable plant growth material. Abstract 776-8. Proceedings of the American Society of Agronomy and the Geological Society of America Meetings, (Houston, TX, October 5-9, 2008).

Noviyanto, A., Purwanto, S. Minardi, and Supriyadi. 2017. The assessment of soil quality of various age of land reclamation after coal mining: A chronosequence study. J. Degrade. Min. Land Manage. 5(1):1009-1018. https://doi.org/10.15243/jdmlm.2017.051.1009

Oldham, J.L. 2014. Lancaster. In F.J. Sikora and K.P. Moore (ed.), Soil Test Methods from the Southeastern United States, Chapter 4.4. Southern Cooperative Series Bulletin No. 419:111117. http://aesl.ces.uga.edu/sera6/PUB/MethodsManualFinalSERA6.pdf. (accessed December 2018)

OSU. 2006. Gypsum for Agricultural Use in Ohio--Sources and Quality of Available Products. Ohio State University Extension Fact Sheet, ANR-20-05. http://ohioline.osu.edu/factsheet/anr20. (accessed December 2018).

Pierzynski, G.M., J.T. Sims, and G.F. Vance. 2000. Soils and environmental quality. $2^{\text {nd }}$ edition. CRC Press, New York, NY. 459 pp.

Pribyl, D.W., 2010. A critical review of the conventional SOC to SOM conversion factor. 
Geoderma 156:75-83. https://doi.org/10.1016/j.geoderma.2010.02.003

Read, J.J., A. Adeli, J.C. McCarty, and G.G. Feng. 2018. Cotton response to residual poultry litter: Leaf area, nitrogen removal, and yield. Agron. J. 110:2360-2368. https://doi.org/10.2134/agronj2018.05.0348

Read, J.J. G.E. Brink, J.L. Oldham, W.L. Kingery, and K.R. Sistani. 2006. Effects of broiler litter and nitrogen fertilization on uptake of major nutrients by Coastal bermudagrass. Agron. J. 98:1065-1072. https://doi.org/10.2134/agronj2005.0221

SAS Institute. 2010. SAS/STAT User's Guide. Version 9.3 edition, SAS Institute, Inc., Cary, NC.

SERA IEG 6. 2009. Procedures used by state soil testing laboratories in the southern region of the United States. In H.J. Savoy (ed.) Southern Cooperative Series Bulletin \#190-D of the Southern Extension Research Activity-Information Exchange Group-6 (SERA-IEG-6), Clemson Experiment Station, Clemson University, Clemson, SC. 25 pp. http://aesl.ces.uga.edu/sera6/PUB/srbull190aug09version.asp. (accessed December 2018).

Sharpe, R.R., H. H. Schomberg, L. A. Harper, D. M. Endale, M. B. Jenkins, and A. J. Franzluebbers. 2004. Ammonia volatilization from surface-applied poultry litter under conservation tillage management practices. J. Environ. Qual. 33:1183-1188. ttps://doi.org/10.2134/jeq2004.1183

Shrestha, B.M., B.R. Singh, B.K. Sitaula, R. Lal, and M. Bajrachary. 2007. Soil aggregate- and particle-associated organic carbon under different land uses in Nepal. Soil Sci. Soc. Am. J. 71:1194-1203. https://doi.org/10.2136/sssaj2006.0405

Shrestha R.K, and R. Lal. 2008. Land use impacts on physical properties of 28 years old reclaimed mine soils in Ohio. Plant Soil 306: 249-260. https://doi.org/10.1007/s11104-008-9578-4

Sistani, K.R., G.E. Brink, A. Adeli, H. Tewolde, and D.E. Rowe. 2004. Year-round soil nutrient dynamics from broiler litter application to bermudagrass. Agron. J. 96:525-530. https://doi.org/10.2134/agronj2004.5250

USDA. 2009. Census of agriculture. Volume 1, Geographic Area Series, Part 51. AC-07-A-51. U.S. Department of Agriculture and National Agricultural Statistics Service. Washington, DC. http://www.agcensus.usda.gov/Publications/2007/Full_Report/usv1.pdf (accessed July 2018).

Walkley. 1947. A critical examination of a rapid method determination of organic matter in soils - effect of variations in digestion conditions and of inorganic constituents. Soil Sci. 63:251- 
Journal American Society of Mining and Reclamation, 2019 Vol.8, No.2

257. https://doi.org/10.1097/00010694-194704000-00001

Zhang, H. 1994. Organic matter incorporation affects mechanical properties of soil aggregates. Soil Tillage Res. 31:263-275. https://doi.org/10.1016/0167-1987(94)90085-X 